

\section{Research methodology}

Content analysis was used to explore the concept of the business case and to summarise the findings of the literature reviewed. The following processes were used:

- Create a list of key search terms. Key terms are derived from the research topic and include synonyms.

- Identify the source for primary searches. The identification of relevant articles was carried out using online databases such as Scopus, IEEE Xplore and Google Scholar.

- Inclusion and exclusion criteria were developed to narrow the number of research articles, that is:

- Articles that are specific to the business case. Much of the literature reviewed comes from backward reference searches, and scans of recent years of journals like the Project Management Journal and the International Journal of Project Management.

- Articles on themes related to the business case like project governance, causes of ITB project failure and knowledge management.

- Articles that merely use the term 'business case' as a synonym for 'justification', such as 'the business case for nursing training', were not used.

A coding frame was used to categorise and analyse the results of the selected performance criteria adopted in this research, which were later used to conceptualise the various themes related to the business case. Figure 1 illustrates the themes, and shows that 'business case processes' and 'business case information needs' are close to the core.

Each theme is assigned a unique 'theme tag' in the reference manager tool, which is used to search for relevant papers during the writing on a particular topic. The main tags used for this article are 'PROCCT' - processes to create and track the business case - and 'INFOCR, INFOTR' information to create and track the business case. Each tag may be used multiple times for a particular article. Thus, each selected idea has a tag, and article page number, in the 'Research Notes' section of the reference manager tool. When writing about business case information, it is possible to seek relevant ideas, even where articles cover several themes. Such references contribute to Tables 1-3, which outline business case information, and to corresponding Tables 1-A1-3-A1 in Appendix 1, which also give the source and use of each information type, as well as at least one reference.

Some judgement is used as to the level of detail, for example, 'Enterprise Environmental Factors' is treated as a single information type, even though it could potentially break down into multiple information types, depending on the project (PMI 2017).

Having extracted the information types, they are mapped, in Table 4, against the business case content elements derived from reference texts, to give some assurance that nothing important has been overlooked.

\section{Literature review}

\section{Information technology or business projects and the business case}

The following background on ITB projects offers a perspective on their unique aspects and success rate. Peppard, Ward and Daniel (2007) find that IT deliverables alone are insufficient, and that business changes are needed to take advantage of them, to produce business benefits. This means that an ITB project has two parts: developing the IT products and using them to create value (Ward, Daniel \& Peppard 2008). Moreover, the two parts are carried out by ITB staff, respectively, who often have different backgrounds and use different terminology. Nevertheless, communication between them is essential as neither group knows all aspects of the project (Sauer \& Reich 2009; Zwikael \& Smyrk 2012). Information technology or business projects that arise in all industry sectors are known to be challenging, and surveys show that up to $20 \%$ of ITB projects fail, with a further $40 \%$ being challenged, resulting in considerable wasteful expenditure (Joseph, Erasmus \& Marnewick 2014; Standish 2014).

An effectively used business case can do much to address such challenges. A business case is a formal document to set out the rationale for a project investment, justify it and hence to get management commitment and authorisation to proceed. As such, it summarises anticipated benefits while considering alternative options and recommending a preferred solution. It provides an overview of the scope of work, the costs, the time frame and the risks. The business case, owned by the project sponsor or business owner, is subject to review and ongoing viability testing throughout the project's lifetime (Cooke-Davies 2005; Franken, Edwards \& Lambert 2009; OGC 2009; PMI 2017).

The business case not only supports project governance from inception, through IT delivery and eventually to benefits realisation, but it also supports the governance of a portfolio of projects, where project selection and prioritisation are needed (Müller et al. 2014). Thus, the business case contributes to success and minimises the risk and impact of failure in the following ways (Einhorn \& Marnewick 2016):

- The business case contains the justification for the project.

- By creating and tracking it, stakeholders get a better understanding of the benefits, costs and risks of the project, leading to informed decisions.

- It enables the project to be prioritised against other viable projects.

- The business case, when updated at the end of the planning phase, confirms that the project remains justified.

- Business case reviews allow ongoing optimisation of the project in response to business and other changes, inside or outside the organisation.

- Finally, after IT deliverables are live, the business case allows results to be compared with expected benefits, thus ensuring that none are overlooked. 


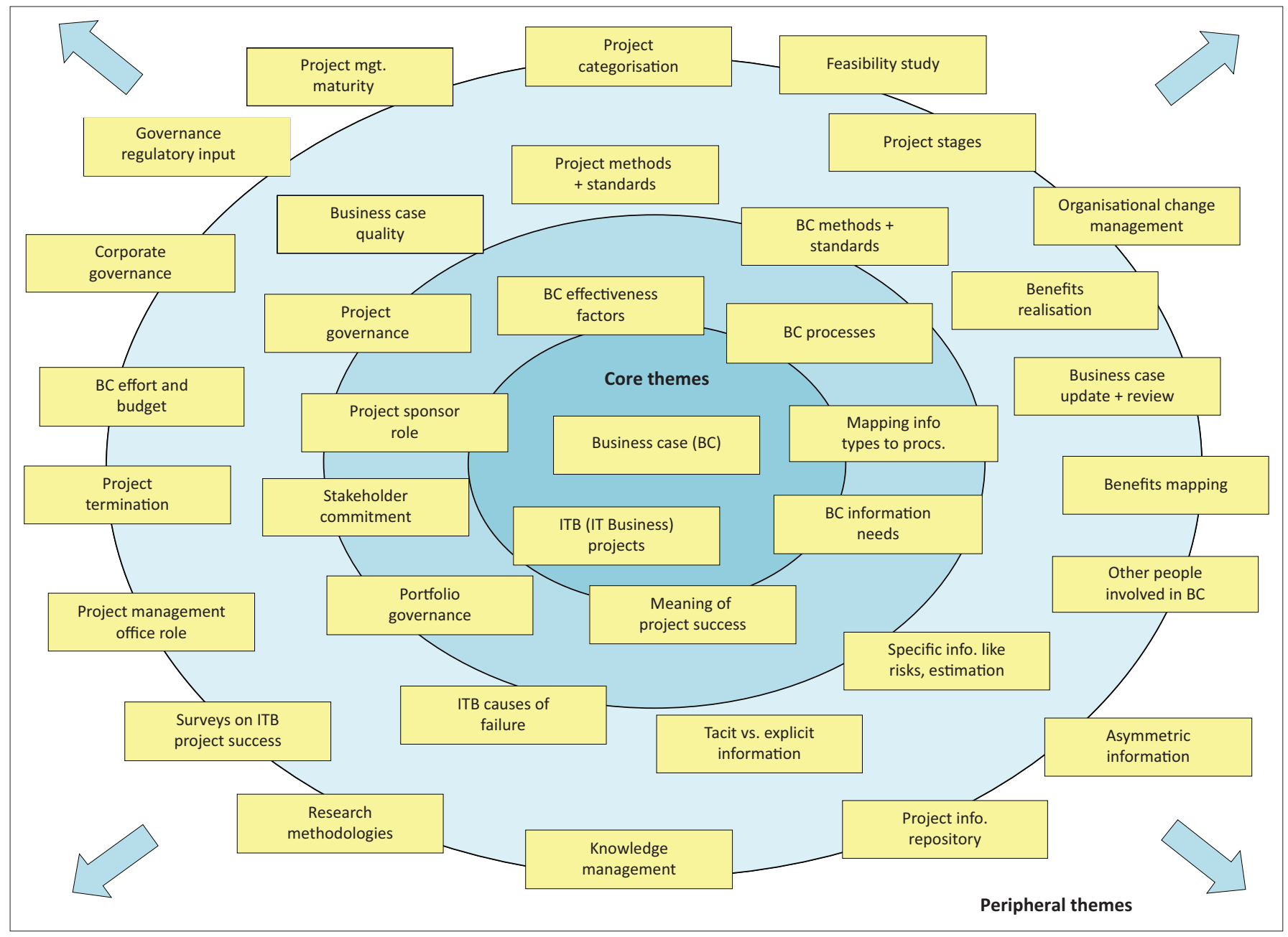

BC, Business case; ITB, Information technology business.

FIGURE 1: Illustration of themes related to the business case.

\section{The business case processes}

To achieve these benefits, a number of processes need to be followed to create and track the business case. The detail and purpose of each process, and their literature references, may be found in Einhorn and Marnewick (2016). The processes are grouped into 'process groups', illustrated in Figure 2, which are in broad chronological sequence. The process groups are described in the paragraphs that follow. Process groups 1-3, for creation of the business case, are generally done preproject. In process group 4, approved projects are prioritised and resourced, while process groups $5-8$ are done after project initiation. If a project happens to be initiated without a business case, then process groups 2 and 3 should be done early in the immediately following project planning phase.

Process group 1 covers preparation for the business case. A high-level project proposal is submitted to the decisionmaking authority, which might be responsible for the portfolio of projects in the organisation. It states the business drivers, and sometimes a mapping is done of proposed benefits, to the business processes changes, and IT deliverables, on which they depend. The proposal is evaluated in terms of business priorities. If it is selected, the project sponsor is confirmed and authorisation given to expand the proposal into a business case; if not, the proposal is rejected and archived.

Process group 2 covers the groundwork for the business case. It might involve considerable investigation, involving the main stakeholders, whose requirements and decision criteria need to be understood. The expected business benefits are detailed with their estimated value over time, and intangible benefits noted. Responsibility for achieving each benefit is assigned to a person, indicating how it will be measured. The main implementation alternatives are considered, and the preferred one stated. The initial scope definition is then done for the preferred alternative, which includes the business process changes, and any organisational changes, required to enable the benefits. An initial risk assessment is conducted, and costs are estimated with a contingency amount to cover risk.

Process group 3 covers assembly, review and presentation of the business case. Based on the groundwork, explanations and estimation methods are documented with necessary evidence, while the underlying assumptions, dependencies and constraints are set out. Where appropriate, the overall financial benefit is calculated, and recommendations are 


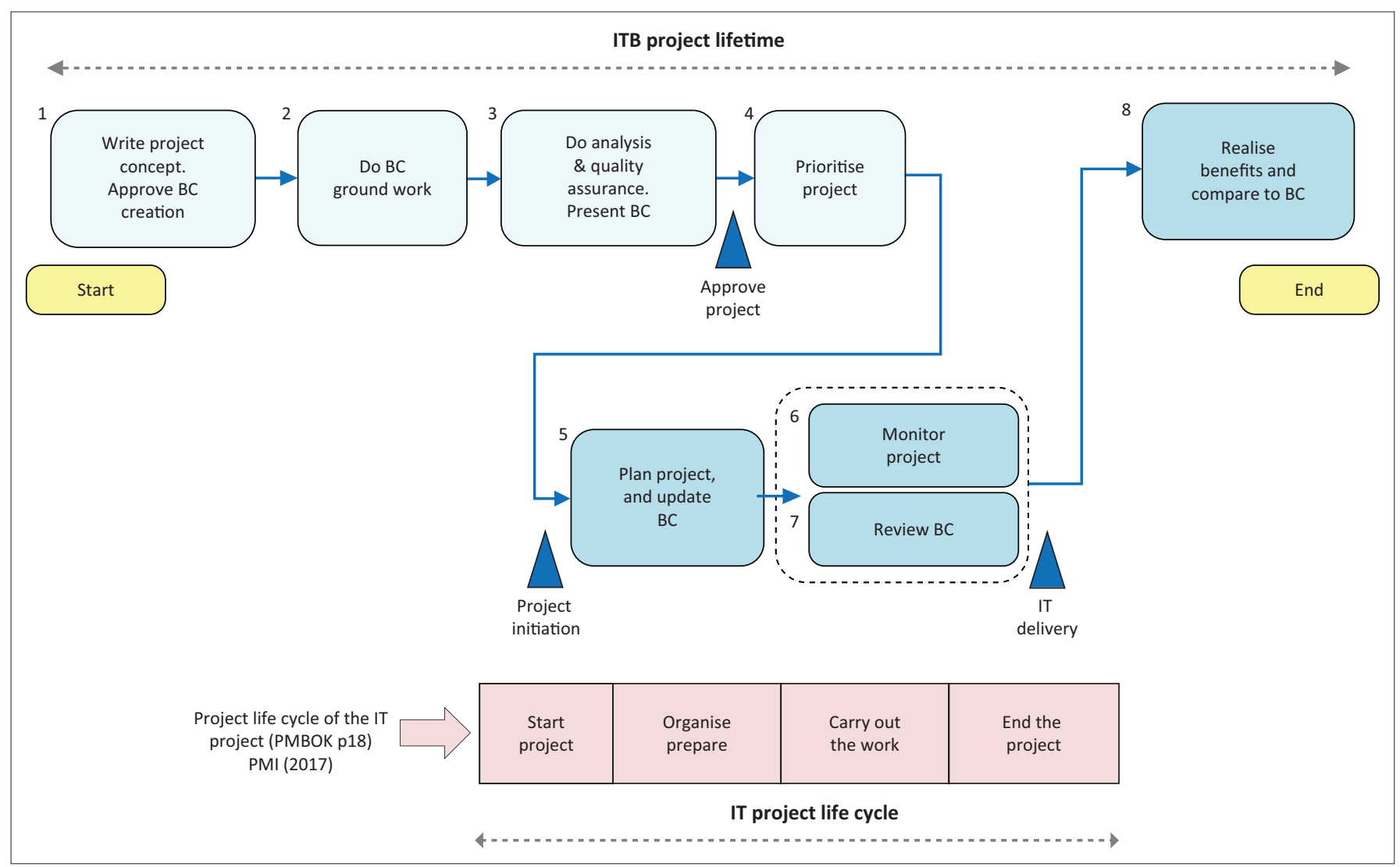

BC, Business case; ITB, Information technology business.

FIGURE 2: Business case process groups mapped to the IT project life cycle.

stated, emphasising the key themes. Quality assurance is performed to ensure that content is sound, relevant and clear, preferably involving an independent reviewer for major initiatives. Finally, the business case is presented to key stakeholders, leading to a decision or a request for further investigation. Once again, if the business case is rejected, it is archived for future reference.

Process group 4 covers prioritisation of projects that have been approved. It could involve several processes, depending on the governance mechanisms in the organisation. The outcome is a decision whether and when the project will be initiated, based on resource availability.

Process group 5 involves integrating information from the business case into the project plan and benefits realisation plan. At the end of planning it is important to ensure that the business case still aligns to the plan, and remains viable. Future reviews involving the business case should form part of the plan.

Process group 6 covers regular monitoring and reporting of project scope, schedule, costs and risks.

Process group 7 involves ad hoc or planned reviews. During the reviews the business case should be updated and checked for ongoing viability.

Process group 8, the last group, involves measurement and assessment of outcomes. Realised benefits are compared with those in the business case and action taken where there is a significant shortfall. After the final assessment, lessons learned are documented to inform future projects.

The eight process groups, which cover the ITB project's lifetime, should ideally be followed in the sequence given, but in practice there is usually iteration. For example, assumptions may be revisited during later project stages, and constant reprioritisation is done during projects that follow an agile methodology. Processes within the groups are often omitted, sometimes justifiably and sometimes to the detriment of the project.

\section{The research problem}

It emerges from Maes, De Haes and Van Grembergen (2014) that even where the process groups, and their processes, are well understood, following them is not easy. An inhibitor is the difficulty of gathering relevant information, in sufficient detail, at the appropriate times, throughout the project's lifetime (Einhorn \& Marnewick 2016). Therefore, the research problem is: 'There is a lack of understanding of the information required for the business case, resulting in its ineffective use'.

The goal of this article is to understand what information may need to be gathered, depending on the context of the project, and to confirm that it covers the main content elements of the business case. 


\section{The relationship between business case processes and information}

Figure 3 provides a model that shows the linkages between the business case process groups and the business case information categories. The information types that make up the information categories are described in subsequent sections. The need for the model arose, when it became apparent that much of the information required during tracking, is different from information that is available when the business case is first presented (Brandon 1998; OGC 2009; Samset \& Volden 2015). So, additional information is generated during planning, and still more during execution and benefits realisation. The model, constructed from the process groups in Figure 2 and the points at which information becomes available, is referred to when introducing the information categories, setting the stage for detailing the information types within the categories.

One purpose of gathering information is to inform governance decisions. As suggested in the earlier subsection on processes, governance decisions can be taken at any time, but the points, at which they are typically needed, are denoted by diamonds marked ' $\mathrm{D}$ '. Decisions could be to continue the project, make changes or stop the project (Larson \& Gray 2014). The figure illustrates the case where all decisions are to continue the project.

To address the research problem, it is essential to understand what information to seek at different times in the project's lifetime. Such information is categorised into the yellow, green and pink categories in Figure 3, and their interaction with the business case process groups is as follows:

- Information to create the business case (yellow) serves as an input to the first four process groups, as shown by the arrows ' $a, b, c, d$ '. The information ' $a$ ' needed for the first group would be at a high level and might lack detail. Arrow ' $c$ ' is double-ended, as the analysis and quality assurance processes, both use information and generate further information. Information ' $\mathrm{e}$ ', from the approved business case, is a major input to project planning (Cooke-Davies 2005).

- Information from project planning (green) is used in a number of ways. It may update the business case ' $\mathrm{f}$ ', as more detail emerges. It also creates information ' $\mathrm{g}$ ', like planned values, that enables the project to be tracked during execution. Here, 'tracking' covers both monitoring of progress and business case review.

- Information for project review (pink) is gathered as the project is executed, like progress and actual costs. Such information is compared to what was planned, and related back to the business case. The comparisons (' $h$ ' and ' $i$ ') should indicate whether the project, or benefits realisation, is according to plan, or whether an ad hoc review is needed. Whether scheduled or ad hoc, such a review could lead to governance decisions.

As indicated by the double-ended arrows, all business case process groups, after project start, both use and generate information. Also, because the business case is updated regularly, the 'to create' and 'from-planning' information is effectively used in all subsequent processes (shown by fainter arrows in the figure).

\section{Information required by the business case processes}

In this section, the information identified earlier is expanded on using colours corresponding to information categories in

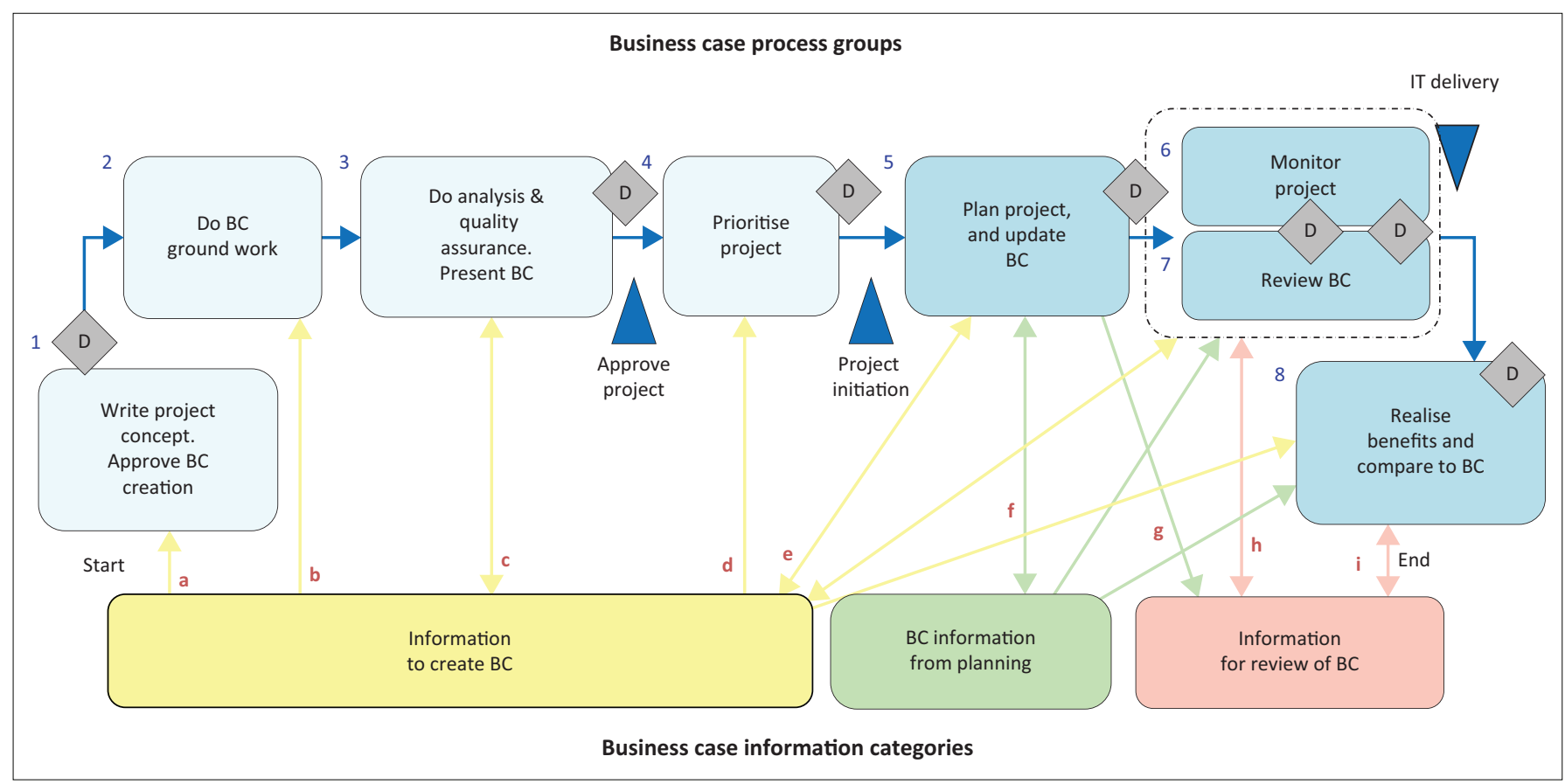

$\mathrm{BC}$, Business case; IT, information technology.

FIGURE 3: The information technology or business case process and information-flow conceptual model. 
Figure 3. Further detail of each information category is given in Appendix 1.

\section{Information to create the business case}

Information to create the business case is itemised in Table 1.

There is a fine distinction between business case information and domain information, where 'domain' refers to the business, design or technical aspects. Some high-level domain information might be included to ensure effective communication with stakeholders, but detail would be contained in specifications and designs that are usually done after the business case has been created.

Some of the 'to-create' information types may appear in earlier project proposal or concept documents (Larson \& Gray 2014). Most of the information would subsequently inform the project plan and benefits realisation plan

\begin{tabular}{|c|c|}
\hline Number & Required information to create the business case \\
\hline 1 & $\begin{array}{l}\text { Project categorisation or type. For example: } \\
\text { Mandatory/Operational/Strategic }\end{array}$ \\
\hline 2 & $\begin{array}{l}\text { Names of sponsor and key stakeholders (including benefit and } \\
\text { change owners) }\end{array}$ \\
\hline 3 & Project description (high level) \\
\hline 4 & Business drivers (corporate imperatives supporting the need for the project) \\
\hline 5 & Business goals (or investment objectives) \\
\hline 6 & Business requirements (high level) or stakeholder expectations \\
\hline 7 & Project objectives (high level) \\
\hline 8 & Corporate strategy alignment \\
\hline 9 & Alternative options to meet business goals (high level) \\
\hline 10 & Results of a feasibility study, pilot study or proof of concept (PoC) \\
\hline 11 & $\begin{array}{l}\text { Results of analysis using financial techniques (like NPV) and non-financial } \\
\text { techniques }\end{array}$ \\
\hline 12 & Complexity factors and assessment \\
\hline 13 & $\begin{array}{l}\text { Critical success factors (CSFs): Inputs that must be in place to achieve } \\
\text { success }\end{array}$ \\
\hline 14 & Assumptions relating to any other information or aspect of the project \\
\hline 15 & Constraints/dependencies (stated and handled similarly to assumptions) \\
\hline 16 & Benefits expected (currently or at the time of project approval) \\
\hline 17 & $\begin{array}{l}\text { Benefits: estimated monetary value (where agreed), indicating } \\
\text { sensitivity to assumptions }\end{array}$ \\
\hline 18 & Benefits: how they will be measured and owned \\
\hline 19 & Impact on existing operations (also known as 'dis-benefits') \\
\hline 20 & $\begin{array}{l}\text { Project scope with deliverables (high level), including benefits realisation } \\
\text { activities by business }\end{array}$ \\
\hline 21 & Project scope exclusions (what will not be done in the project) \\
\hline 22 & Diagrams (to clarify any aspect of the project) \\
\hline 23 & Project success criteria (over and above realisation of benefits) \\
\hline 24 & $\begin{array}{l}\text { Cost estimates (direct, indirect, operational), indicating sensitivity to } \\
\text { underlying assumptions }\end{array}$ \\
\hline 25 & Time estimates (high level) and proposed milestones \\
\hline 26 & Resource requirements (people/skills, finance) and their availability \\
\hline 27 & Risks (negative and positive): identified and described \\
\hline 28 & Risks: analysed with response actions and an estimate of residual cost \\
\hline 29 & Contingency/management reserve (cost and time) \\
\hline 30 & $\begin{array}{l}\text { Organisational process assets (OPA), including lessons learned from } \\
\text { past projects }\end{array}$ \\
\hline 31 & Enterprise environmental factors (EEF), mainly internal to the organisation \\
\hline 32 & $\begin{array}{l}\text { External factors, which may be political, economic, social, technological, } \\
\text { legal or environmental }\end{array}$ \\
\hline 33 & Sustainability aspects \\
\hline 34 & Relationship to other projects \\
\hline
\end{tabular}

(OGC 2009). The information needs to be checked for validity throughout the project's lifetime.

Some metadata could apply to all business case information. For example, the project name may already have been proposed by stakeholders and approved by the sponsor (OGC 2009). Likewise the project number or code may have been assigned by portfolio management. Such metadata, including author and date, would be placed in all documents, often in header or footer text, to give context to the document's contents. Refer to Table 1-A1 for detailed information on the 'to-create' information category.

\section{Information, from project planning, used in business case processes}

Information that arises during project planning and is used in business case processes is itemised in Table 2. OGC (2009) recognises that planning gives considerable detail that was not available earlier, and that the business case is likely to change as a result. Therefore, OGC (2009) refers to an 'outline' business case when approval is given to start the project, accepting that information, at this point, is approximate and subject to change.

'From-planning' information also sets up baselines, like planned values, that are used to monitor the project, and review the business case, during and after project execution. Some information types only affect the business case indirectly. For example, schedule risk analysis might show

TABLE 2: Business case information from project planning.

\begin{tabular}{|c|c|}
\hline Number & Business case information derived from project planning phase \\
\hline 35 & Work breakdown structure (WBS) \\
\hline 36 & Revised detailed estimates of cost, time and resources \\
\hline 37 & Stakeholder responsibilities (including project team) \\
\hline 38 & Quality requirements and non-functional specifications \\
\hline 39 & Schedule information showing: dates, duration, dependencies, resources \\
\hline 40 & $\begin{array}{l}\text { Planned value (PV) control figures for earned value management (EVM) } \\
\text { purposes }\end{array}$ \\
\hline 41 & Updated risk information \\
\hline 42 & $\begin{array}{l}\text { Schedule risk analysis (SRA) - sometimes done late in planning, and } \\
\text { repeated periodically }\end{array}$ \\
\hline
\end{tabular}

TABLE 3: Business case information for project review.

\begin{tabular}{ll}
\hline Number & Business case information required for project review \\
\hline 43 & Schedule progress and changes \\
44 & Earned value (EV) at specified dates \\
45 & Actual cost (AC) at a specified dates \\
47 & EVM derived data at specified dates \\
48 & Issues information (title, description, dates, people, alternatives, resolution) \\
49 & $\begin{array}{l}\text { Risks, new and updated } \\
50\end{array}$ \\
$\begin{array}{l}\text { Change control information (change description, benefits, impacts, } \\
\text { change status) }\end{array}$ \\
51 & $\begin{array}{l}\text { Regular project information: status, recent progress, short-term plan, } \\
\text { major issues and risks }\end{array}$ \\
52 & $\begin{array}{l}\text { End-project info.: achievements, approved changes, time/cost } \\
\text { performance, remaining work }\end{array}$ \\
53 & $\begin{array}{l}\text { Lessons learned (ongoing and at end of project) } \\
\text { Measurements of business benefits, and assessment of strategic } \\
\text { benefits, post-project }\end{array}$ \\
55 & $\begin{array}{l}\text { Cost of termination (only if a review indicates that the project may } \\
\text { no longer be justified) }\end{array}$ \\
\hline
\end{tabular}




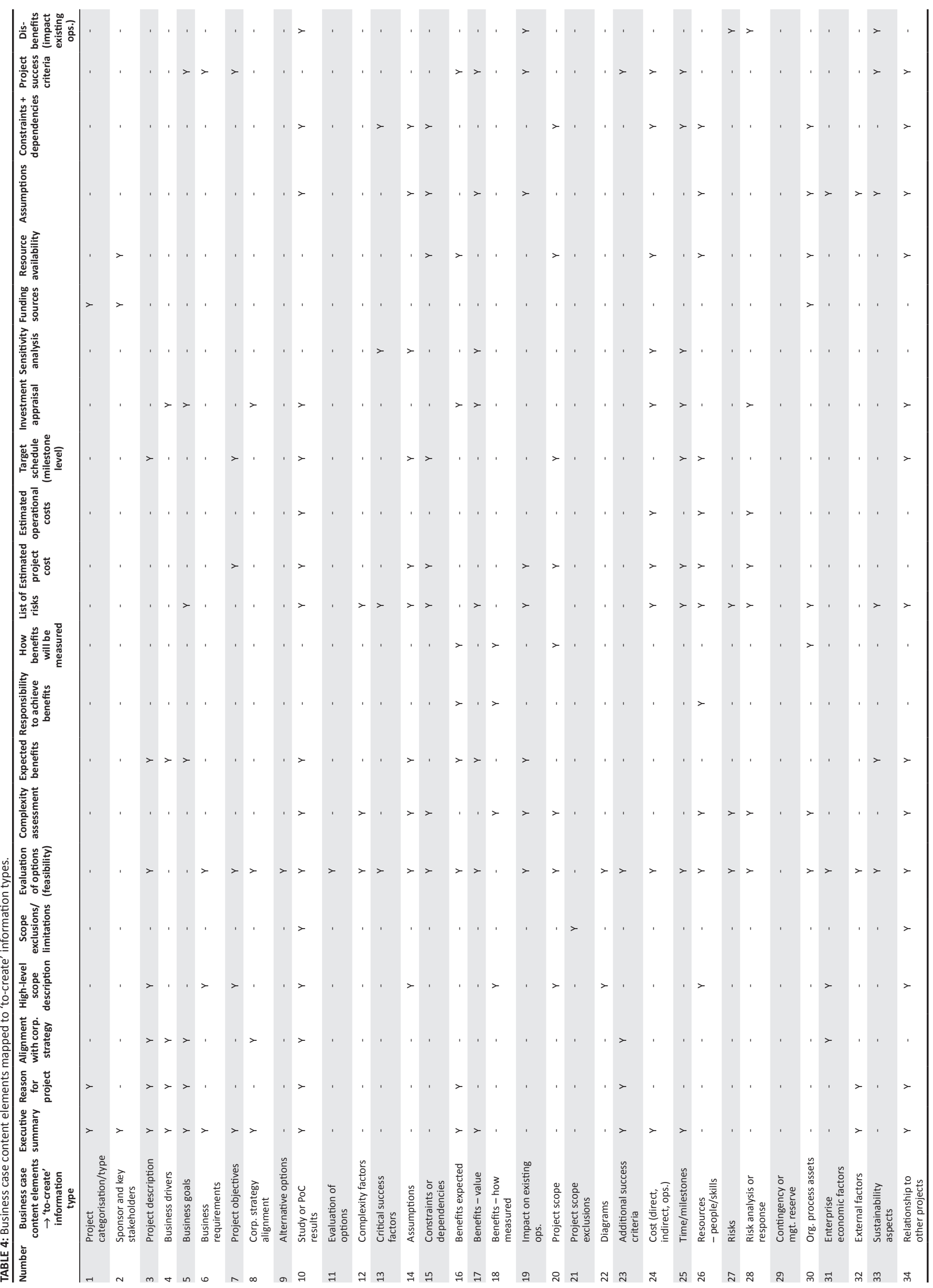


that the schedule is overoptimistic, which, in turn, affects risk, and hence the business case. Refer to Table 2-A1 for detailed information on the 'from planning' information category.

\section{Information, for project review, used by business case processes}

Information generated during project execution, which is used to monitor progress and to review the business case, is itemised in Table 3.

Herman and Siegelaub (2009) assert that every aspect of the business case can change over time, with the acquisition of additional information. Therefore, the business case must be reviewed periodically to check that it is still viable and justified, using the additional information types from execution. Information would be generated regularly, when required or at defined milestones, and is collectively referred to here as 'for-review' information types (colourcoded pink). They should be used to monitor project progress by comparing them to the project plan which is, in turn, derived from the business case. Information to monitor the project (numbers 43-51) is relevant because any significant deviation from plan, or new issue or risk, might trigger a review of the business case if it causes a key stakeholder to expresses doubts as to the project's ongoing justification. The 'for-review' information types would also be used for gate reviews and other reviews, where the business case is updated and validated (Larson \& Gray 2014). An important benefit of tracking is that it allows the business case to be used to guide the project throughout ongoing decisionmaking. Refer to Table 3-A1 for detailed information on the 'for review' information category.

\section{Mapping of 'to create' information, to business case content elements}

In Table 4, the 'to-create' information types are mapped to the business case content elements derived from reference texts (APM 2006; ISACA 2012; ITGI 2008; Messner 2013; OGC 2009; PMI 2017; Vidal, Marle \& Bocquet 2011). The fact that each content element is fed by at least one information type serves as a crosscheck that types are not obviously missing. It indicates the more important relationships, but not every possible one, as business cases are contextual, and what applies to one project may not apply to another. Table 4 is created by considering each business case content element (horizontal axis) in turn, and indicating with a ' $\mathrm{Y}$ ' the likely 'to-create' business case information types (vertical axis) that might be needed to inform it. Thus, to determine which information should be sought to inform one content element, the reader would go vertically down from the content element, and left from every ' $\mathrm{Y}$ ' to find the likely information types.

Some content elements, like 'evaluation of options', may require many information types for each option considered. Other content elements, like 'funding sources', may require only a few information types. Thus, the mapping shows that there are 'many-to-many' relationships, where one business case information type maps to multiple business content elements and vice versa. The number of relationships, in turn, demonstrates the complexity of the business case, and that judgement is needed to select the most relevant information.

\section{Conclusions and the requirement for future research}

From the literature it is concluded that ITB projects, which have unique challenges, have an unsatisfactory success rate. This situation can be improved through project governance, underpinned by business cases, which, if used effectively, ensure the ongoing justification for investments in ITB projects. Business cases, in turn, need well-understood processes and information, for them to be effective. These processes and information types are summarised in the conceptual model given in Figure 3.

The processes from Einhorn and Marnewick (2016) and the information types presented in this article can be put to immediate use to guide project sponsors, other executives and also project management practitioners, who all play key roles in project governance. The information types underline the importance of establishing relationships with stakeholders who must provide the information, as well as the judgement to determine what is relevant. Although the information types covered are in the context of traditional or agile ITB projects, most information types would apply to any project.

Nevertheless, there are avenues for further research. Although it is necessary to understand the business case process groups, and the information that feeds and arises from them, such understanding on its own may be insufficient to engender effective use of the business case. There are many organisational factors that facilitate or inhibit the gathering of information and the business case processes themselves. An example might be the attitude of business users towards providing information, and being fully involved in many aspects of the project. Research into these business case effectiveness factors is therefore a future objective.

\section{Acknowledgements Competing interests}

The authors declare that they have no financial or personal relationships that may have inappropriately influenced them in writing this article.

\section{Authors' contribution}

F.E. was responsible for the conceptualisation, literature review and drafting of the article. C.M. was responsible for the final review and quality review.

\section{References}

APM, 2006, APM body of knowledge, 5th edn., Association for Project Management Buckinghamshire, UK.

Brandon, D.M., 1998, 'Implementing earned value easily and effectively', Project Management Journal 29(2), 11-18. https://doi.org/10.1177/875697289802900204 
Cadle, J., Paul, D. \& Turner, P., 2010, Business analysis techniques - 72 Essential tools for success, BCS the Chartered Institute for IT, London.

Cooke-Davies, T., 2005, 'The executive sponsor - The hinge upon which organisational project management maturity turns?', Paper presented at the PMI Global Congress Proceedings, Edinburgh, Scotland, 23-25 May.

Coombs, C.R., 2015, 'When planned IS/IT project benefits are not realized: A study of inhibitors and facilitators to benefits realization', International Journal of Project Management 33(2), 363-379. https://doi.org/10.1016/j.ijproman.2014.06.012

Crawford, L., Hobbs, J.B. \& Turner, J.R., 2005, Project categorization systems - Aligning capability and strategy for better results, PMI, Pennsylvania, PA.

Denolf, J.M., Trienekens, J.H., Wognum, P.M., Van der Vorst, J.G.A.J. \& Omta, S.W.F., 2015, 'Towards a framework of critical success factors for implementing supply chain information systems', Computers in Industry 68, 16-26. https://doi org/10.1016/j.compind.2014.12.012

Disterer, G., 2002, 'Management of project knowledge and experiences', Journa of Knowledge Management 6(5), 512-520. https://doi.org/10.1108/13673270 210450450

Einhorn, F. \& Marnewick, C., 2016, 'A practical model for the effective use of the business case in IT Projects', Paper presented at the PMSA Conference 2016, Johannesburg, 9-11 November.

Flyvbjerg, B. \& Budzier, A., 2011, 'Why your IT project may be riskier than you think', Harvard Business Review 89(9), 23-25. https://doi.org/10.2139/ssrn.2229735

Franken, A., Edwards, C. \& Lambert, R., 2009, 'Executing strategic change: Understanding the critical management elements that lead to success', California Management Review 51(3), 49-73 (Spring 2009). https://doi.org/10.2307/ 41166493

Herman, B. \& Siegelaub, J., 2009, 'Is this really worth the effort? The need for a business case', Paper presented at the PMI Global Congress, Orlando, FL, October.

Hornstein, H.A., 2015, 'The integration of project management and organizational change management is now a necessity', International Journal of Project Management 33(2), 291-298. https://doi.org/10.1016/j.ijproman.2014.08.005

IPMA, 2009, PM Baseline Version 3.0, IPMA - Projekt Management Austria, Austria.

ISACA, 2012, COBIT 5: Enabling processes, IL.

ITGI, 2008, Enterprise value governance of IT investments - the Val IT Framework 2.0 extract, viewed 13 January 2018, from https://www.isaca.org/.../Val-IT.../Val-ITFramework-2.0-Extract-Jul-2008.

Joseph, N., Erasmus, W. \& Marnewick, C., 2014, 'The idle state of information and communication technology project management', Journal of African Busines 15(3), 184-196. https://doi.org/10.1080/15228916.2014.956641

Keen, J.M., 2011, Making technology investments profitable: ROI road map from business case to value realization, Wiley, Hoboken, NJ.

Larson, E.W. \& Gray, C.F., 2014, Project management: The managerial process, International edition, 6th edn., McGraw-Hill Education, New York.

Maes, K., De Haes, S. \& Van Grembergen, W., 2014, 'The business case as an operational management instrument-A process view', ISACA Journal 4, 29-36.

Marnewick, C., 2014, 'The business case: The missing link between information technology benefits and organisational strategies', Acta Commercii 1, article \# 208.

Messner, W., 2013, Making the compelling business case, Palgrave Macmillan, Gordonsville, VA.
Meyer, W.G., 2014, 'The effect of optimism bias on the decision to terminate failing projects', Project Management Journal 45(4), 7-20. https://doi.org/10.1002/ projects, 21435

Müller, R., Pemsel, S. \& Shao, J., 2014, 'Organizational enablers for governance and governmentality of projects: A literature review', International Journal of Project Management 32(8), 1309-1320. https://doi.org/10.1016/j.ijproman.2014.03.007

Musawir, A.U., Serra, C.E.M., Zwikael, O. \& Ali, I., 2017, ‘Project governance, benefit management, and project success: Towards a framework for supporting organizational strategy implementation', International Journal of Project Management 35(8), 1658-1672. https://doi.org/10.1016/j.ijproman.2017.07.007

Nelson, R.R. \& Morris, M., 2014, 'IT project estimation: Contemporary practices and management guidelines', MIS Quarterly Executive 13(1), 15-31.

OGC, 2009, Managing successful projects with PRINCE2, 5th edn., in A. Murray (ed.), TSO (The Stationery Office) on behalf of Office of Government Commerce, Norwich.

Peppard, J., Ward, J. \& Daniel, E., 2007, 'Managing the realization of business benefits from IT investments', MIS Quarterly Executive 6(1), 1-11.

PMI, 2013, PMBOK - Guide to the project management body of knowledge, 5th edn., Project Management Institute, Pennsylvania, PA.

PMI, 2017, PMBOK - Guide to the project management body of knowledge, 6th edn., Project Management Institute, Pennsylvania, PA.

Ross, J. \& Beath, C., 2002, 'Beyond the business case: New approaches to IT investment', MIT Sloane Management Review 43(2), 51-59.

Samset, K. \& Volden, G.H., 2015, 'Front-end definition of projects: Ten paradoxes and some reflections regarding project management and project governance', International Journal of Project Management 34(2), 297-313. https://doi.org/ 10.1016/j.ijproman.2015.01.014

Sauer, C. \& Reich, B.H., 2009, 'Rethinking IT project management: Evidence of a new mindset and its implications', International Journal of Project Management 27(2), 182-193. https://doi.org/10.1016/j.ijproman.2008.08.003

Silvius, A.J.G. \& Schipper, R.P.J., 2014, 'Sustainability in project management: A literature review and impact analysis', Social Business 4(1), 63-96. https://doi.or $\mathrm{g} / 10.1362 / 204440814 \times 13948909253866$

Standish, 2014,. Chaos Report, viewed 01 February 2018, from https://www. projectsmart.co.uk/white-papers/chaos-report.pdf.

Thamhain, H., 2013, 'Managing risks in complex projects', Project Management Journal 44(2), 20-35. https://doi.org/10.1002/pmj.21325

Uzzafer, M., 2013, 'A contingency estimation model for software projects', International Journal of Project Management 31, 981-993. https://doi.org/10.1016/j.ijproman. 2012.12.002

Vanhoucke, M., 2010, 'On the dynamic use of project performance and schedule risk information during projecttracking', Omega 39(4), 416-426. https://doi. org/10.1016/j.omega.2010.09.006

Vidal, L.-A., Marle, F. \& Bocquet, J.-C., 2011, 'Measuring project complexity using the analytic hierarchy process', International Journal of Project Management 29(6), analytic hierarchy process', International Journal of Proje

Ward, J., Daniel, E. \& Peppard, J., 2008, 'Building better business cases for IT investments', MIS Quarterly Executive 7(1), 1-15.

Zwikael, O. \& Smyrk, J., 2012, 'A general framework for gauging the performance of initiatives to enhance organizational value', British Journal of Management 23 S6-S22. https://doi.org/10.1111/j.1467-8551.2012.00823.x 


\section{Appendix 1}

\section{Tabulation of information types by category}

The following tables give the detail of the business case information types required to create the business case, to plan the project and for project review.

Tables are created by review of papers with theme tags (see 'Literature Review' above) related to business case information. It is not possible to cite all references as some information types, like project risk, are covered in numerous papers.

The column 'Source of Information' indicates the people or documents from which information is obtained. Where 'business case team' is mentioned, it means the person(s) tasked with creating the business case. The column 'Use of Information' illustrates where information adds value during the processes.

TABLE 1-A1: The business case 'to-create' information category.

\begin{tabular}{ll}
\hline Number & Type of information \\
\hline 1 & $\begin{array}{l}\text { Project categorisation or type. For example, } \\
\text { Mandatory/Operational/Strategic }\end{array}$ \\
2 & $\begin{array}{l}\text { Names of sponsor and key stakeholders } \\
\text { (including benefit and change owners) }\end{array}$ \\
\hline 4 & $\begin{array}{l}\text { Project description (high level) } \\
\text { Business drivers (corporate imperatives } \\
5\end{array}$ \\
\hline 6 & $\begin{array}{l}\text { Busporting the need for the project) } \\
\text { Business requirements (high level) or } \\
\text { stakeholder expectations }\end{array}$ \\
\hline
\end{tabular}

\section{Source of information}

Organisation decides on categorisations and assigns them to projects

From sponsor and general discussion

From sponsor or designated project manager or business analyst

From sponsor or senior business users

From sponsor or senior business users

From sponsor, business analyst or other business stakeholders

Agreed between sponsor and business case team

Project objectives (high level)

Corporate strategy alignment Alternative options to meet business goals (high level)

10 Results of a feasibility study, pilot study or proof of concept (PoC)

11 Results of analysis using financial techniques Results of analysis using financial techniques
(like NPV) and non-financial techniques

12 Complexity factors and assessment

13 Critical success factors (CSFs): inputs that must be in place for the project to be successful at all levels

14 Assumptions relating to any other information or aspect of the project

Constraints/dependencies (stated and handled similarly to assumptions)

16 Benefits expected (currently or at the time of project approval)

17 Benefits: estimated monetary value (where agreed), indicating sensitivity to assumption

18 Benefits: how they will be measured and owned

19 Impact on existing operations (also known as 'dis-benefits')

20 Project scope with deliverables (high level), including benefits realisation activities by business

21 Project scope exclusions (what will not be done in the project)

22 Diagrams (to clarify any aspect of the project)

23 Project success criteria (over and above realisation of benefits)

24 Cost estimates (direct, indirect, operational), indicating sensitivity to underlyin assumptions

25 Time estimates (high level) and proposed milestones

26 Resource requirements (people/skills, finance) and their availability statement

From expert input, surveys of available solutions, supplier proposals

From reports or from people involved in PoC

From analysis by the business case team,

From business case team, or feasibility study team

From discussion with sponsor and stakeholders

From expert input or inferred by the business case team

From expert input or inferred by the business case team

From sponsor and key stakeholders

From analysis by business case team based on stakeholder input

From the business stakeholders responsible for benefits realisation From business stakeholders and expert input

From stakeholders and business case team. Input from business requirements, lessons learned by the sponsor

From stakeholders and business case

From stakeholders

From estimates by experts, typically using analogous or 'reference class' techniques (Flyvbjerg \& Budzier 2011; Meyer 2014)

From scope, resource availability and dependencies. Influenced by business need

Use of information

Guides portfolio balance. May indicate priority, and extent of benefits realisation activity

Crawford Hobbs and Turner (2005); Larson and Gray (2014); Ross and Beath (2002)

Plan communication. Confirm availability of PMI (2013); Ward et al. 2008 funding

Give stakeholders an overview of the project $\quad$ APM (2006); PMI (2013)

Support the goals, and hence justify the project

Confirm the purpose of the project

Expand on business goals, inform high-level scope, and input to functional system specifications

State what the project must achieve, and by when, to support business goals

States which strategies are supported by the project any earlier feasibility study, pilot study or or feasibility study team

From the business case team and agreed

Starting point for selecting project approach/ concept. For comparison with the 'do nothing' option

Resulting reports feed several information types. They support selection of the preferred option, and allocation of resources

Provides the basis on which to select and recommend the preferred option

Influence selection of alternatives and identification of risks

OGC (2009); Ward et al. (2008)

Ward et al. (2008)

ISACA (2012); Maes et al. $(2014)$

APM (2006)

Larson and Gray (2014)

Herman and Siegelaub (2009); OGC (2009)

ISACA (2012); Messner (2013); Ward et al. (2008)

SACA (2012); Messner (2013)

Messner (2013); Vidal et al. (2011)

(2015) during planning and execution. Check that CSFs are realistic

Allow validation in reviews by stakeholders. Messner (2013), Maes et al. Risks may relate to assumptions being incorrect (2014)

Inform the project plan, and allow regular Messner (2013) OGC (2009) review of their status

Informs benefits realisation plan and its assessment. Input to project justification

Input to financial justification

Herman and Siegelaub 2009); Keen (2011)

Messner (2013); OGC (2009); Ward et al. (2008)

Input to project scope, and benefits realisation Herman and Siegelaub review

Input (negative) to justification. May result in mitigating scope action

(2009); Ward et al. (2008)

Herman and Siegelaub

(2009); OGC (2009)

Informs plan and benefits realisation, including Coombs (2015); Hornstei organisational change management aspects (2015); Ward et al. (2008)

Set the boundaries of the project, and stakeholder expectations

APM (2006); Larson and Gray (2014)

Help stakeholders to gain a sound

understanding of the project

Support assessment of project outcomes

APM (2006)

APM (2006); Marnewick (2014)

Confirm that project meets financial criteria, to Herman and Siegelaub prioritise the project, and to monitor progress from a cost point of view

Give initial understanding of main project events with planned dates, and also input to related

(2009); Messner (2013); Ward et al. (2008)

with plan
projects

Herman and Siegelaub

(2009); ISACA (2012)

Informs feasibility, cost, preferred option, and

IPMA (2009); PMI (2013) timing of project 
TABLE 1-A1 (Continues...): The business case 'to-create' information category.

\begin{tabular}{|c|c|c|}
\hline Number & Type of information & Source of information \\
\hline$\overline{27}$ & $\begin{array}{l}\text { Risks (negative and positive): identified and } \\
\text { described }\end{array}$ & $\begin{array}{l}\text { From stakeholders and risk tools or } \\
\text { checklists }\end{array}$ \\
\hline 28 & $\begin{array}{l}\text { Risks: analysed with response actions and } \\
\text { an estimate of residual cost }\end{array}$ & By business case team and risk specialist \\
\hline 29 & $\begin{array}{l}\text { Contingency/management reserve } \\
\text { (cost and time) }\end{array}$ & $\begin{array}{l}\text { From qualitative or quantitative risk } \\
\text { analysis }\end{array}$ \\
\hline 30 & $\begin{array}{l}\text { Organisational process assets (OPA), } \\
\text { including lessons learned from past projects }\end{array}$ & $\begin{array}{l}\text { From knowledge of the organisation, } \\
\text { including internal processes and } \\
\text { historical records }\end{array}$ \\
\hline 31 & $\begin{array}{l}\text { Enterprise environmental factors (EEF), } \\
\text { mainly internal to the organisation }\end{array}$ & $\begin{array}{l}\text { From knowledge of the organisation, like } \\
\text { culture and governance }\end{array}$ \\
\hline 32 & $\begin{array}{l}\text { External factors, which may be political, } \\
\text { economic, social, technological, legal or } \\
\text { environmental }\end{array}$ & $\begin{array}{l}\text { From formal fact finding or tacit } \\
\text { knowledge of stakeholders }\end{array}$ \\
\hline 33 & Sustainability aspects & $\begin{array}{l}\text { From stakeholder view of ongoing } \\
\text { people, financial, environmental factors }\end{array}$ \\
\hline 34 & Relationship to other projects & $\begin{array}{l}\text { From programme and portfolio } \\
\text { management }\end{array}$ \\
\hline
\end{tabular}

\begin{tabular}{ll} 
Use of information & References \\
\hline $\begin{array}{l}\text { Input to risk analysis and resulting in response } \\
\text { actions }\end{array}$ & $\begin{array}{l}\text { Herman and Siegelaub } \\
\text { (2009); Thamhain (2013) }\end{array}$
\end{tabular}

$\begin{array}{ll}\text { Input to risk analysis and resulting in response } & \text { Herman and Siegelaub } \\ \text { actions } & \text { (2009); Thamhain (2013) }\end{array}$

Included in cost estimates and input to the PMI (2013); Ward et al. planning risk register

(2008)

Results in budgeted amounts at project or sponsor level

Input to evaluation of options, decisions and Disterer (2002); PMI (2013) plans

Input to evaluation of options, decisions and

plans

Input to evaluation of options, decisions and plans

Ifluences assessment of benefits and the approach to achieve them

Input to plans for other projects and resource Messner (2013); OGC (2009) utilisation

Note: Please see the full reference list of the article, Marnewick, C. \& Einhorn, F., 2019, 'The business case thrives on relevant information', South African Journal of Information Management 21(1), a978. https://doi.org/10.4102/sajim.v21i1.978, for more information.

TABLE 2-A1: The business case 'from-planning' information category.

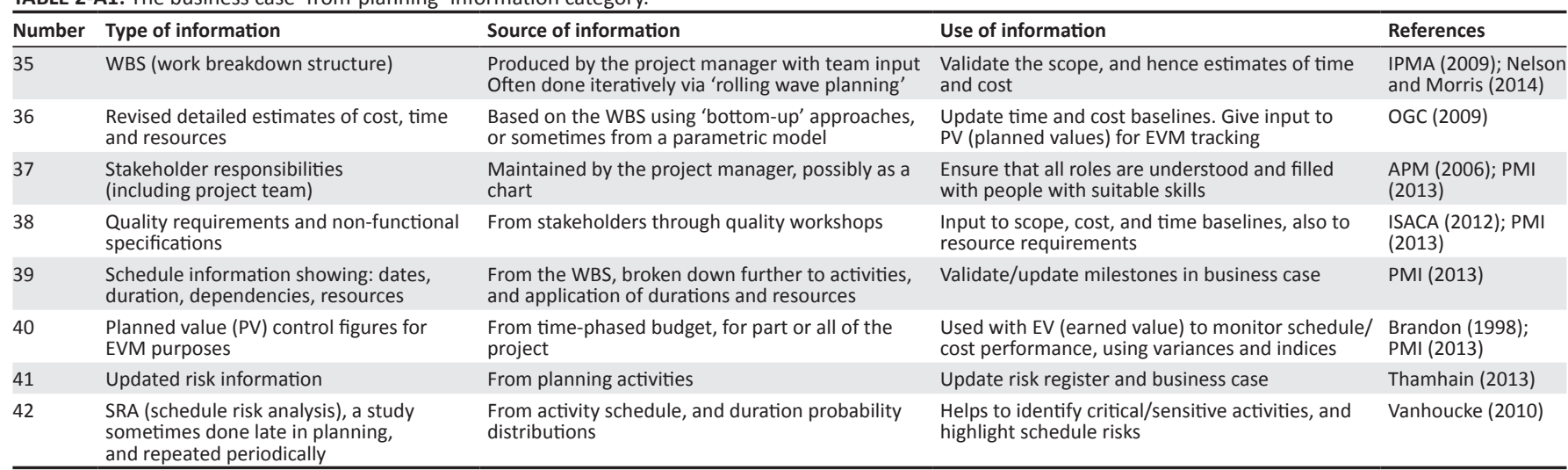

Note: Please see the full reference list of the article, Marnewick, C. \& Einhorn, F., 2019, 'The business case thrives on relevant information', South African Journal of Information Management 21(1), a978. https://doi.org/10.4102/sajim.v21i1.978, for more information.

TABLE 3-A1: The business case 'for-review' information category.

\begin{tabular}{ll} 
Number & Type of information \\
\hline 43 & Schedule progress and changes \\
44 & Earned value (EV) at specified dates \\
45 & Actual cost (AC) at a specified dates \\
\hline 46 & EVM derived data at specified dates
\end{tabular}

47 Issues information (title, description

dates, people, alternatives, resolution)

$48 \quad$ Risks, new and updated

49 Decisions record (description, dates, decision-maker)

$50 \quad$ Change control information. (change description, benefits, impacts, change descrip
status)

51 Regular project information (including status, recent progress, short-term plan, major issues and risks)

52 End-project information (including achievements, approved changes, time and cost performance, remaining work

53 Lessons learned (ongoing and at end of project)

54 Measurements of business benefits, and assessment of strategic benefits, post-project

55 Cost of termination (only if a review indicates that the project may no longer be justified

Source of information

From regular progress tracking

Estimated by PM with input from schedules, as a measure of achievement to-date (using PV as a yardstick)

From project accounts, supplier invoices, timesheets and rates per individual

CPI, SPI (cost, schedule performance indices) and CV, SV (cost, schedule variances) are derived from $\mathrm{EV}, \mathrm{PV}$ and $\mathrm{AC}$

From stakeholders, and owned by project manager

From any stakeholder during ongoing project activity

From sponsor decisions, business case reviews, or meeting minutes

From any stakeholder, and managed between sponsor and project manager

From PM informed by records and project team, often in the form of a dashboard or project report

Produced by project manager, often in the form of an 'end-project report'

From project reviews or stakeholder input

By business users, during benefits and postimplementation reviews, guided by benefits plan

Investigation taking into account contractual, human, and risk factors. Also the effect on relate projects or parts of the business
Use of information

Input to EV estimates

Used to determine cost and schedule variances and indices, and/or 'earned schedule'. Feeds regular reports

Used with $\mathrm{EV}$ to determine cost variances and indices. Hence track cost performance. Feeds

regular reports

Used to monitor progress, estimate \% completion, Brandon (1998); and forecast completion date and costs. Feeds PMI (2013) regular reports

Allows issues to be recorded, managed, and OGC (2009) reported. Some issues may affect project viability Thamhain (2013) Update risk register and monitor response actions. OGC (2009). Selected risks are reported

Inform stakeholders and ensures common understanding

Allows changes to be tracked and reported on. Explains changes to scope, schedule and cost baselines, and hence business case changes

Keep stakeholders informed. Trigger review action OGC (2009); when needed. Provide project history for reviews

Informs all stakeholders. Input to future related projects

Used to inform future activities, and future projects (e.g. potential risks)

Allows sponsor and executive management to gauge project success

Input to decision whether to continue, chang or terminate the project
References

PMI (2013)

Brandon (1998);

Thamhain (2013)

Larson and Gray (2014)

OGC (2009);

PMI (2013)

PMI (2013)

OGC (2009); PMI (2013)

Herman and Siegelaub (2009);

PMI (2013)

Herman and

Siegelaub (2009):

OGC (2009)

Meyer (2014)

Note: Please see the full reference list of the article, Marnewick, C. \& Einhorn, F., 2019, 'The business case thrives on relevant information', South African Journal of Information Management 21(1), a978. https://doi.org/10.4102/sajim.v21i1.978, for more information. 